IP Periodica Polytechnica

Social and Management

Sciences

24(1), pp. 25-33, 2016

DOI: $10.3311 /$ PPso. 7945

Creative Commons Attribution (i)

RESEARCH ARTICLE

\section{Marketing and the Symbolic Value of a Performing Arts Institution: The Case Study of the Czech National Theatre}

\author{
Zuzana Chytková ${ }^{*}$, Jitka Černá ${ }^{1}$, Miroslav Karlíček ${ }^{1}$
}

Received 31 January 2015; accepted after revision 30 June 2015

\begin{abstract}
Apart from aspects such as the market orientation or the artistic vision, one possible element that should be taken into consideration when defining performing arts institutions' marketing is its symbolic value. In this paper we are presenting the case study of the Czech National Theater, which has had a special position within the Czech national history. We have conducted in-depth interviews and ZMET interviews to explore the meaning the theater holds for Czech consumers. We draw on the notions of the extended self and collective memory to show how through particular rituals the experience of attending artistic performance can form a part of the consumers' collective sense of self. We consider the implications for performing arts institutions' marketing.
\end{abstract}

\section{Keywords}

performing arts marketing, national identity, self

\footnotetext{
${ }^{1}$ Department of Marketing, Faculty of Business Administration, University of Economics, Prague, Czech Republic

${ }^{*}$ Corresponding author, e-mail: zuzana.chytkova@vse.cz
}

\section{Introduction}

"The National Theatre is the embodiment of the will of the Czech nation for a national identity and independence." (from the website)

Numerous studies have been concerned with different aspects of performing arts' marketing strategy (e.g. Crealey, 2003; St James and Colbert, 2011) performing arts products still require an audience, and new product development following a trend of marketing application outside the strictly commercial sphere (Karlíček, Novinský, and Tahal, 2014). Our paper involves the symbolic aspect of performing arts institutions and its possible use for their marketing strategy. In particular, we are exploring how the "process of immersing oneself in an aesthetic experience" can have a deeper meaning and can take part in the formation of consumer's self not only on the individual level, but also on the group level.

In particular, we will try to uncover the meanings consumers attribute to attending National Theater in light of the collective memory of the nation. We will explore how the theater is constructed as a symbol of the national identity and is used in the construction of consumers' selves through the consumption process. In this way, we will show empirically that the aesthetic experience can form a part of the consumers' extended self and as such offers a great opportunity and threat at the same time to the organization's marketing. This allows us to explore new marketing grounds using particular academic knowledge that the (cultural) industry itself does not possess and offer, thus, academia-industry collaboration in a way similar to what was described by Petruska (2002).

\section{Analytical framework: The symbolic meaning of an aesthetic experience and the consumer's extended self}

The study takes place in the context of consumer culture, in which the meanings of aesthetic experiences are constituted through acts of production and consumption (Venkatesh and Meamber, 2006). Through the acts of consumption, aesthetic 
experiences take on meanings and become symbols, ultimately used by consumers in the construction of their selves.

The aesthetic experience is at the intersection of production and consumption. Like other goods, the meanings it conveys stem from the culturally constituted world (McCracken, 1986) and are taken up and transformed by the consumer in the pursuit of identity formation (Venkatesh and Meamber, 2006). It is this intersection that we set out to explore. We concentrate on this consumer part of the experience, as consumers are those cultural actors who "transform the cultural products into objects of meaningful consumption experiences" (Venkatesh and Meamber, 2006:p.13) and we try to uncover the meanings created by the attendance of the Czech National Theater.

Our work stems from the notion of extended self and seeks to understand what role can an aesthetic experience play in constituting it. The context we have chosen is particularly apt for such task. As will be shown in the following section, the Czech National Theater represents a part in people's sense of the national self, which Czech consumers often consider as more central to their self-identity than the individual self (Holý, 2001). In this way we also answer the call forwarded by Hug (2012) to study media consumption in a more complex manner considering also its social and cultural aspects.

The self is a way in which consumers understand who and what they are and consumer goods are an important way in which the self is constructed and communicated (Belk, 1988; Kleine III, Kleine, and Kernan, 1993). The concept of the self as an entity that is co-defined by what the person perceives as his/hers (his/her possessions), was first introduced in psychology (James, 1890). Within the same discipline, it was then tested by Prelinger (1959) in his test of James' (1890) division between self-region and not-self region, in which he designed an experiment to test 160 items in eight content categories, among which possessions figured, and showed that they scored relatively high as part of people's self. That consumers forge a meaningful sense of self through the marketplace offerings has been amply shown in the literature (Arnould and Thompson, 2005; Belk, 1988; Sirgy, 1982; Price, Arnould, and Curasi, 2000). Belk (1988) has demonstrated that material possessions play part in consumers' creation, enhancement and preservation of a sense of identity (p.150). McCracken (1986) has shown how consumers create their self through the continuous appropriation of goods' meanings. The crucial role of possessions in consumers' self identity is demonstrated also by studies of people who have lost their possessions due to robbery or natural disaster, which have shown that such events tend to be followed by feelings of identity loss (Belk, 1988). Similarly, people in adverse life position, e.g. the homeless, also use the scarce possessions in defining and maintaining a sense of self (Hill, 1991; Hill and Stamey, 1990).

Consumption is not only crucial for the definition of the individual self, but also its extended parts. Self-identity can be seen as a multilayered phenomenon, in which some possessions express the inner, more individual self, while others represent the collective identity (family, subculture, nation). One of the elementary ways of confirming one's collective identity is through shared consumption symbols (Belk, 1988). In this way, a house helps to define and maintain a family identity (McCracken, 2005), and importance is given to family possessions, which become inalienable as consumers "seek to preserve group identity by collecting and making tangible an ancestral past" (Curasi, Price, and Arnould, 2004). Similarly, social class identification or ethnic identities are co-constructed through consumption of particular goods and services (Askegaard et al., 2005; Holt, 1997; Peñaloza, 1994), while "communities, nations, and other group levels of self are similarly constituted via monuments, buildings, books, music, and other created works" (Belk, 1988:p.160). In this way, consumption of these goods adds to a feeling of belongingness to a group at the individual level, which contributes to feeling as a whole, while at a group level it allows for greater group cohesion. Thus, the loss of a national symbol (e.g. the World Trade Center) can be seen and experienced as a threat to the self and can excite a wave of national solidarity and patriotism (Skitka, 2005).

Objects and sites of aesthetic experiences can be seen as one possible part of the extended self, particularly "those persons, places, and things to which one feels attached." (Belk, 1988:p.141). Csikszentmihalyi and Halton (1981) have demonstrated that objects of contemplation (such as art or photos) grow in importance over objects of action (such as musical instruments, plants, stereos) in people's self-formation with growing age. Such evolution is indicative of the growth in importance of social bonds over the individual ego-centric self, as the question is no longer "who am I", but rather "how do I fit in"? (p.100). In the context of our study, such claim resonates with assertions that younger people do not present a strong national identity, but are more ego-centric (e.g. Seidlova, 2003). Performing arts then represents the so-called "high culture", which plays a prominent role in national identity construction.

Different sites and experiences of arts, however, have different meaning and can play a different role in the consumer's extended self. As other products and services, works of art reflect underlying meanings that originate in the culturally constituted world (McCracken, 1986; Venkatesh and Meamber, 2006). Thus, meanings of gender, class, status, age, or of national identity are instilled in different pieces, sites and experiences of art.

In some cases, certain works of art such as monuments, plays, books, musical compositions can be the crystallization of a particular group's collective memory. Collective memories are a means through which communities, including nations, create and maintain a sense of self "through the active construction of a shared past" (Thompson and Tian, 2008:p.596). Collective memories are a way, in which a group recreates its past through remembering significant events through certain rituals 
(Halbwachs, 1992). Thus, works of art become invested with particular meanings through collective memories. In our context, the National Theater is an example of such artistic site and monument, because its meaning is mostly created by the Czechs' collective memories. These collective memories are at their time produced and reproduced by stories described in history books and school textbooks or recounted by teachers, guides, parents, etc. and will be described in the following section.

While objects, sites and pieces of art have a meaning, it is not said that this meaning must be incorporated into people's lives. Because works of art, like other media, are encoded (Onfray, 2001; Venkatesh and Meamber, 2006), to consume its meaning and incorporate it into one's self requires the consumer to be adequately literate and dominate the code (Hug, 2012). However, in our case, the consumers are mostly in possession of the code since they intimately know the object (i.e. the National Theater) through education and other collective story telling and it can be thus said that it is a part of their extended self (for different ways of incorporating objects into one's self, see Belk, 1988). The appropriation of the object's meaning and the affirmation of the consumer's identity then takes place through a consumption ritual (McCracken, 1986). Rituals as means of meaning incorporation and identity affirmation work both at individual and collective levels. The family identity for instance becomes affirmed through rituals of use, display, and maintenance of family inalienable possessions (Price, Arnould, and Curasi, 2000), while national identity can be affirmed through the consumption of landmarks, leaders, sports teams or monuments (Belk, 1988).

We are presenting a case study of the Czech National Theater arguing that its building, inner furnishings, as well as its performances form a part of the Czech consumers' extended self. By attending a performance at the Theater, consumers affirm their national identity and incorporate the Theater into their self through particular rituals. The knowledge of these processes can then be employed in the design of the National Theater's and other performing arts' institutions' marketing strategies. It particularly offers an insight into what really represents the performing arts institutions' product and how to design it. In order to illustrate the importance of the Czech National Theater as a context for our study, in the following section we will introduce its history and its place within the Czech national movement.

\section{Context: National Theater as a historical symbol of national identity}

The history of the Czech nation was often characterized by fight for independence. After an epoch of an independent and relatively strong Bohemian kingdom in the Middle Ages, it became part of the Austrian (later Austro-Hungarian) empire in 1526. Most of the history afterwards was marked by forced germanization of the population, public life and culture through imposition of German language or forced re-catholicization of the protestant population, accompanied by stripping the Czech nobility off the right to administer the country and the transfer of the total country control to Austria. As a reaction to these processes, together with the growing nationalism in Central Europe in the first half of the $18^{\text {th }}$ century, the 1790 s marked the beginning of the Czech national reawakening that took place mostly in the realm of culture. Carried out especially by the intelligentsia, the movement sought to revive the Czech language in both written and spoken form, the Czech culture and awaken nationalism among laymen. The Czech National Theater was born as a part of this movement (Kočí, 1978).

Theater was a crucial part of the awakening process, as it was one of the most important instruments used to educate common people (next to schooling and books). Yet, there was no entirely Czech theater in the $19^{\text {th }}$ century Prague. Exponents of the intelligentsia requested a permission and called for a national collection of funds to construct the National Theater, the first theater that would be entirely Czech. Although the popular collection was not the only source of funding for the theater's construction, it was enormously successful and it is a popular understanding, reinforced by collective story telling, that it was built by the nation for itself. This idea is also documented by the inscription above the stage, which states "Nation to itself".

Foundation stones brought from around the country were set in 1868 and the theater opened for the first time in 1881, but in the same year it burnt down. A new popular collection was called for and a million florins was collected within 47 days (a clerk would make around 300 a year at those times). The theater reopened in 1883 performing an opera based on Czech mythology written by the Czech composer Smetana especially for this occasion (Benešová, Flídrová, and Kučera, 1999).

Given these origins of the National Theater, the place it occupies within the Czech culture can be understood easily. It stands as a symbol for national identity, as a symbol of a fight for political and cultural independence. Yet, another crucial element to be taken into consideration here is the constitution of the Czech national identity as such. The Czechs construct themselves as a nation, whose important characteristic is its high culture (Holy, 2001). However, national identity tends to be constructed in relation to "the other", it defines who we are politically and culturally by delimiting the cultures and entities that we are not (Vlachova and Rehakova, 2004). Because of the frequent periods of oppression, the Czech national identity has been constructed first in relation to Austrians, later during the World War II to Germans, during the communist rule and Soviet occupation in relation to Russians and until the division of Czechoslovakia to Slovaks (Holy, 2001; Vlachova and Rehakova, 2003). Mostly, the national identity was set around the idea of the oppressed nation fighting for its own state, which was also reflected in people's readiness to sacrifice for the nation (Seidlova, 2003). In such setting, National Theater 
as a symbol of the national identity, of being Czech, has a clear definition and position in people's minds. If we were to use marketing terms, National Theater as a brand had a great positioning on the performing arts market. Today, as Czech Republic is an independent state, "the other" is unclear and so becomes the national identity. It has been shown that the Czech National Identity becomes weaker and less important in Czechs'self-identification (Vlachova and Rehakova, 2003) and that especially young people do not find self-sacrifice for the nation necessary (Seidlova, 2003).

In this setting, the question of NT's position as a symbol of national identity becomes crucial. Understanding how attending a performance here is experienced in connection to the (national) identity can not only give a powerful marketing tool to the theater itself, but can also help marketers of other performing arts institutions to see novel ways of positioning of their own products.

\section{Methodology}

In order to illustrate the deep meaning that the National Theater holds for the young Czech consumers and to describe the way, in which they incorporate this symbolic meaning into their self, we have conducted in-depth interviews with 8 respondents aged 16-32, and additional 5 semi-structured depth interviews following the method called Zaltman metaphor elicitation technique (ZMET) with respondents aged 25-35. ZMET is a projective technique and like other projective techniques it is used to stimulate respondents' thinking process, in order to uncover meanings that tend to be taken for granted and not readily accessible to the consumers themselves (Moisander and Valtonen, 2006).

ZMET is a hybrid technique based on findings from verbal and non-verbal communication, visual sociology, visual anthropology, literary critique, semiotics, cognitive neuroscience or phototherapy (Coulter, 2007). It is based on the presumption that thoughts are image-based and are not communicated predominantly verbally, and humans organize the world around metaphors (Zaltman, 1997). It is thus easier to access deeper, unconscious thoughts through visual cues and metaphors. The data collection consists in a semi-structured interview that revolves around images the respondents had been asked to bring to the interview. By letting the respondents pick the images, they are given the opportunity to process the topic better, while also letting them describe the topic in his/her own terms (Zaltman, 1997). After discussing each of the images separately, the respondents are asked to create a collage that would represent how they perceive the topic.

Our in-depth interviews included questions regarding respondents' feelings towards the nation and their attitudes towards and experiences of the National Theater. The ZMET interviews followed the tenets of the method, which is based on visual elicitation that facilitates the uncovering of deep metaphors consumers use to understand the world (Zaltman and Coulter, 1995). Respondents were asked in advance to choose 6-8 images that for them represent the National Theater. Through particular interview techniques, deep meanings associated with the theater were then identified.

All interviews were recorded and transcribed verbatim. The transcribed text was then analyzed by the iterative process of categorization, abstraction and comparison of different interviews among each other and each interview to the whole (Spiggle, 1994).

\section{Empirical evidence}

We have set out to explore the meaning the National Theater holds for the Czech consumers, to see if and how it forms their extended self at the national identity level, and ultimately to find how these findings can be used in the marketing strategy of the National Theater and other performing arts institutions. Our main findings revolve around the following four key areas.

First, we found that the collective memory of the National Theater's history almost invariably penetrated our respondents' accounts. This collective memory then materializes in the physical reality of the theater, where particular aspects of its history (as known from the collective story-telling) take form in particular facets of the building. This is of great marketing interest not only for the National Theater. Because theaters can be seen as providing services, whose crucial characteristic is their intangibility, i.e. the impossibility to be seen before they are bought, the material aspects of the place where the service is provided are a significant "quality signal" for the customers (Kotler and Armstrong, 2001) and thus becomes central to the theater's marketing.

The collective memory, however, materializes also in the imagined quality of the performances, where the Theater's particular place within the history lends it an aura of high quality. This is also an interesting finding for marketing due to the intrinsic characteristic of services, whose quality can hardly be anticipated and needs to be inferred from other signals. Our findings suggest that these signals need not be only those traditionally described in literature (i.e. adding tangible aspects to intangible services), but marketers can also work with popular myths and stories originated in collective memory, or other cultural discourses.

Finally, our findings show that the symbolic value of the theater instantiated through the collective memory and (commercial) myth making becomes incorporated into respondents' self through particular rituals of attendance. This again can be of interest to marketers, as the theater visit can be seen as a service encounter and experience that adds value to the "product" through the particular rituals.

We will address each of these aspects of our respondents' accounts in the following. 


\subsection{Collective memory of the National Theater and its symbolic value for the national identity}

Our respondents see the National Theater first and foremost as a symbol of the nation itself, particularly as a symbol of its cultural independence. Because historically the cultural independence was symbolized by the existence of the Czech language, and because theater was the principal means to maintain and diffuse the language, they are inevitably connected. As Lubos says:

[National Theater] is a symbol. A symbol of the Czech nation, of the language, definitely a symbol. It is something one carefully looks up to, it is something higher, something precious that has to be cared for, that has to be taken care of. (Lubos, 22)

Drawing on the collective memory of the theater, especially the history of the public fund raising, the respondents attribute it an almost mythical power to unite the nation and act as the symbol of its national and cultural independence.

Interviewer: How do you think it differs from other national theaters in other countries?

Respondent: It is connected to the last picture and it's about solidarity and togetherness, which is linked to the re-building of the theater. People united and together they collected the money for the reconstruction. It is as if the negative event united the nation, at least in people's minds. (Anna, 25)

It is a symbol that has its place in history [...] I think it's a bigger symbol because, if it's really true, that people got together, made a collection, that's the known history, I take it as a reason, that it was built together out of this money with common efforts. "Nation to itself", right? (Prokop, 24)

The crucial moments in the often-mentioned history of the theater are the burning of the theater the same year it opened and the renewed popular collection to fund the renovation. These moments are particularly important for the national symbolism of the theater, since they point to the nation's cohesion in the face of hardship. Symbolically, this story, which is still vivid in the collective memory, represents the nation's cohesion, strength and autonomy in the face of the adverse historical conditions that threatened to strip the Czechs off their national identity (i.e. the Austrian rule, the German rule, the Soviet rule). These two historical moments were thus repeated by our respondents time and again.

Interviewer: If a foreigner asked you about the National Theater, what would you say about it?

Well, its brief history, when it was built, when the foundation stone was set, that it burnt down and was built again. (Klara, 25)

There is fire [on this picture]. I remember that the National
Theater burnt down in the past and I see that as a major event in its history. [...] It had to be hard for the people, because the nation had lost its theater, a major cultural site. (Erika, 25)

These quotes show that the National Theater represents a material instantiation of the Czech collective memory. Consumers project the history, such as told by the books, teachers and fellow citizens, into the institution. Although the National Theater represents a specific case, these findings show that a cultural institution can have a deeper meaning rooted in the (national) culture. What is more important, however, is the way the meaning becomes materialized, which we will describe in the following.

\subsection{The role of material artifacts in the theater's sym- bolic meaning}

The history of the theater materializes in its physical characteristics that play together with the collective memory to create a particular atmosphere.

When I come there, I feel I am in a place where the history happened, I have a good feeling from it. Also that, even though now it's worse, but also the clothes people wear... It is a bit more free now, but compared to other theaters it is still somehow observed. So it's a higher quality experience. (Prokop, 24)

What Prokop is referring to is the habit to dress up for a theater performance that in the Czech culture was quite diffused until the end of the communist era. In this context, National Theater represents a place, where the traditions are still met and where, therefore, the history can be experienced. Although the possession of particular historical meaning is the prerogative of just a few theaters (in particular the National Theater), what this finding shows is the importance of the experience of theater visit as a whole. The experience, its quality and memorability, is evaluated not only in terms of the quality of the performance, the repertoire, the quality of seating, but also in terms of other components of the experience, e.g. fellow theater attendants. It thus shows that the theater visit experience is complex and multifaceted, and as such must be designed by its marketers.

This is further illustrated by our informants' next accounts. For them, the traditions that can be recalled and relived in the National Theater do not include only the attire, but also the behavior of fellow attendants. It is perceived that attendants' behavior itself is affected for the better when getting closer to the standards of the past.

The environment motivates this kind of behavior [men helping out women with coats]. I think when people are in the National Theater, it affects their behavior for the better. They are more courteous, more gentlemanlike. (Klara, 25) 
While our informants believe better behavior is inspired by the National Theater's specific materiality, this is an aspect that can be adapted by other performing arts institutions in creating an unforgettable experience for their customers (e.g. through imposing particular dress-code or rules).

The materiality of the venue, however, remains important. In the case of the National Theater, other material artifacts that allow time travel and history experience include works of art present on the building or inside the building like statues or paintings, or the artistic fittings like chandeliers.

There is Vojtěch Hynais [a Czech painter, who painted the theater curtain] on the picture. I chose this picture, because when you say National Theater, I imagine the curtain and I imagine him. [...] I imagine the theater's stage and that particular curtain. I sit in the theater and I see the curtain with all the gold and colors. And it feels spectacular, luxurious, as if I went 100 years back in history. (Erika, 25)

The third picture is a beautiful chandelier, paintings and the decorations, which is what comes up in my mind when you say National Theater. I imagine the atmosphere, I imagine that everybody is wearing beautiful clothes, waiting for something, looking forward to something. They are in a beautiful environment, so they are admiring it, the lights. I always look up at the paintings. (Linda, 26)

These material artifacts that symbolize the history of the theater play a significant role in the incorporation of the theater in the self and in affirming the visitors' national identity. Just like described by Belk (1988), objects can become part of the extended self by contamination, in which good and bad aspects of objects attach to people through touch or physical proximity. Through contamination by the material artifacts that symbolize the national identity our respondents incorporate the theater into the self.

Well, when I see the gold, I would like to touch it. It evokes this feeling that it is mine, if I touched it. Sometimes you touch golden objects to be lucky as well. (Lenka, 25)

While the historical materiality of the National Theater affirms its visitors' national identity, other theaters can make use of the same process of contamination in the design of their customers' experience that will affirm their personal or family identities. This process shows that the performing arts institutions' marketing should strive not only to create a particular offer in terms of the repertoire, but also to design the whole experience, making use of material artifacts to render the whole venue "a stage." In this way it is then possible to draw the visitors' experience from the very moment they enter the premises or even before that (as will be shown later) and make it memorable.

\subsection{The quality myth as a part of the collective memory of the National Theater}

The collective memory of the National Theater materializes also in the accounts of the genre and the quality of its performance. Because the theater represents a symbol of the Czech cultural re-birth, the site that stands for the efforts to revive the Czech culture during the time of re-awakening, it is inevitably connected to the artistic production of those time. The visitors, thus, expect the theater to put on traditional plays.

I think the National Theater is seen by most Czechs as a center of the traditional, conservative art, and at the same time as a guarantee for high quality and as a prestigious brand. (Libuse, 26)

At the same time, due to the prominent position of the theater within the national historical accounts what follows is the connotation of prestige the theater holds both for the artists and for its visitors. It is thus a common understanding, reinforced by popular cultural accounts of only the best artists being allowed to work in the theater, that the National Theater's stage is the finest, where only the best performing art in the country can be seen.

People expect to see something different there than in other theaters, a higher quality performance. I see it as the top of quality performance. (Erika, 25)

It is just a symbol of the highest culture. For me it's the greatest theater of all theaters. (Lenka, 25)

It's prestigious to get to work in the National Theater, so it's connected to high quality art. (Michal, 26)

You can always go to the National Theater without a doubt. If I was to decide about attending a performance in a small theater, I would hesitate, if it's going to be good. (Prokop, 24)

The expected high quality of the performance, as well as the expected genre to be seen in the theater can be seen as a result of a particular myth in the sense of Barthes, who defined it as "a chain of concepts widely accepted throughout a culture, by which its members conceptualize or understand a particular topic or part of their social experience" (O'Sullivan et al., 1994:pp.286-287).

The traditional marketing tools to communicate the quality of intangible services reside in rendering the service more tangible through various material "signals" (Kotler and Armstrong, 2001). Our results show, however, that there are different ways of communicating the service quality, e.g. careful public relations management that will construct or draw on a particular popular discourse. This is in line with what has been described by Thompson and Tian (2008) as commercial mythmaking. 


\subsection{Incorporating the symbolic value into the self: the role of rituals}

What transpired from our respondents' accounts was thus their knowledge of the theater's history and the resulting expectations. What also resulted as crucial for our respondents were the rituals associated with visiting this particular theater. The first and most important ritual mentioned was already stated above in connection with keeping the traditions and reliving the past through them. It is the ritual of dressing up for the occasion, which our respondents found as crucial. As Linda says:

I know I will have a nice evening. I will dress up, put on some make up, I will go and have a chat with someone, get a cultural experience. (Linda, 26)

It's different how I dress to the National Theater and how I dress to other places. National Theater is a gala occasion. (Katerina, 16)

It is still something extraordinary for me. With other theaters it became ordinary, but in the National Theater it's still special. If only the dressing up that still keeps in the National Theater, while people already wear normal clothes in other more modern theaters. (Lubos, 22)

The performance itself thus plays only a partial role in the whole experience, which begins long before the actual performance or even the arrival to the theater.

The preparations are connected to what I will be wearing, because I think it's important. When I go to the National Theater, I have to dress smartly, elegantly. When you come to the National Theater, it's the feeling of high standards and the expectation what will the play be like and enjoying the atmosphere, because the National Theater is just beautiful. (Marie, 24)

You definitely can't go there like to a cinema. The smaller theaters, for instance, I attend dressed normally, but going to the National Theater it's necessary to dress a bit better, put on a suit. It's necessary to go through some preparation and not go directly from work. (Michal, 26)

Because the dressing up for the occasion, as well as the atmosphere created by other people in particular attire constitute the material, tangible aspect of the whole experience, we argue that these rituals allow the consumers to incorporate the meanings of the National Theater into their self. Through the careful planning of the whole visit and through the performance of the (commonly known) rituals associated with the theater visit, the consumers are participating in a particular, collectively told story and thus affirming their national identity. This is also demonstrated by the fact that foreign visitors often fail to obey (or indeed know) the rules and are then perceived negatively by the Czech attenders for ruining the atmosphere of the theater and thus the possibility for them to enact the rituals in the right way.
These findings show that when designing a particular performing arts institution's strategy, marketers should understand their "product" not only strictly as the service encounter within the theater, but as an experience that begins long before the actual visit takes place.

\section{Conclusion}

Based on the empirical evidence, we argue that the aesthetic experience of visiting the Czech National Theater constitutes the opportunity for our respondents to affirm their self-identity. Through particular rituals they manage to incorporate the meanings represented by the National Theater into their extended self. In a context of the social turmoil following the fall of the iron curtain, in which the same meaning of national identity has been thrown in doubt, the National Theater has proved to provide a solid ground for its formation and affirmation. As such, its role goes far beyond that of a provider of performance art. The sharing of the specific interpretive codes originated in the collective memory of the group (nation) that lend the National Theater its meaning can be said to overcome what has been claimed by some: that young people do not identify with the nation to such a degree as the older generation due to the missing direct experience with the national oppression (Seidlova, 2001). The collective story telling (particularly through the schooling system) does fill this gap and offers young people the codes that are necessary for the immersion in the experience. Consequently, visiting a performance in the National Theater creates a feeling of belonging to a group (the nation).

The importance of self-identity in the experience of theatre attendance points to its significance for performing arts marketing. In particular, for those organizations that possess specific symbolic meaning that consumers employ in the formation of their self-identity, this meaning forms an asset that should not be left aside. In today's marketplace that sells experiences more than products (Joy and Sherry, 2003), the theater that can offer an experience deeply embedded in the collective and individual memory, has a notable competitive advantage from others.

Since performing arts institutions offer services, they should be managed as service providers, yet with their particularities. One key aspect of their marketing is the definition of the product. Our findings have shown that these institutions should not limit the product to the performance itself, but design the whole experience of the visitors that begins way before they actually reach the performance venue, but also ends long after they have gone. By designing a memorable, exciting experience marketers facilitate the incorporation of the particular symbolic meaning their institution offers. The design of the experience should thus for example include the careful design of all marketing communication that should not be limited to the communication of repertoire. It should include the design of the experience of ticket buying and could include e.g. definition of dress-code, behavior rules, etc. The experience should consider the material aspects of the venue and what 
kind of behavior they facilitate. In this way, it is possible to design a product that will coherently communicate the desired symbolic meaning to its consumers and facilitate its incorporation.

Working on the institution's symbolic meaning can prove to be very fruitful. The symbolic meaning offers a shield against consumer dissatisfaction that might follow an unsuccessful marketing strategy. Consumers are willing to forgive for example a poor quality performance, since they still infallibly get at least one part of the sought experience. In this way, the organization is also somewhat freer in its artistic vision while defining the performance mix. On the other hand, however, this symbolic meaning of the organization itself can present a limitation to the same organizations, if it is too strong and figures prominently in consumers' selves (such as the case of the National Theater). Because consumers perceive it as a part of their extended self (i.e. perceive the institution as theirs) a prolonged lack of expected performance quality can lead to higher consumer dissatisfaction. Marketers should thus be aware of the symbolic meaning their institution possesses and work with it.

Our findings, however, also offer a new viewpoint at the organization's management from the public policy point of view, as the consumption of the institution's product (performing art) strengthens the national identity of the attenders. The vision and mission of the National Theater could therefore involve conscious inclusion of strengthening of national identity as one of its goals. Also, as the symbols of group identity provide "a sense of community essential to group harmony, spirit, and cooperation" (Belk, 1988:p.160), the group itself (in this case the government of the nation) can make use of these symbols to enhance the members' sense of belonging and the inner harmony of the society. This becomes a crucial finding and a powerful tool in times of crisis such as these.

Although our case study is very particular, with a very specific history and particular place within the collective national imagination, it nonetheless shows that the symbolism associated with a certain arts institution brand can play a significant role in its marketing mix and should not be overlooked.

Overall, our case study presents a new dimension that should be taken into consideration in the discussion on the importance of both the market orientation and the artistic vision in a performing organization's product strategy (Crealey, 2003; St James and Colbert, 2011). It shows that the symbolic dimension of the institution itself can offer a significant degree of freedom for the artistic vision, but also binds the theater in the process of marketing mix definition.

\section{Acknowledgements}

This study is a result of the research project "Effective methods for the increase of national and European competitiveness of small and medium enterprises in the field of culture" registered with the Ministry of Culture (program NAKI) under the number MK DF11P01OVV024.

\section{References}

Arnould, E. J., Thompson, C. J. (2005). Consumer Culture Theory (CCT): Twenty Years of Research. Journal of Consumer Research. 31 (4). pp. 868-882. DOI: $10.1086 / 426626$

Askegaard, S., Arnould, E. J., Kjeldgaard, D. (2005). Postassimilationist Ethnic Consumer Research: Qualifications and Extensions. Journal of Consumer Research. 32 (1). pp. 160-170. DOI: 10.1086/426625

Belk, R. W. (1988). Possessions and the Extended Self. Journal of Consumer Research. 15 (2). pp. 139-168. DOI: 10.1086/209154

Benešová, Z., Flídrová, D., Kučera, J. (1999). Národni Divadlo: historie a současnost budovy. [History and present of the building]. Praha: Národní divadlo. (in Czech).

Crealey, M. (2003). Applying New Product Development Models to the Performing Arts: Strategies for Managing Risk. International Journal of Arts Management. 5 (3). pp. 24-33.

URL: http://www.jstor.org/stable/41064795

Csikszentmihalyi, M., Halton, E. (1981). The Meaning of Things: Domestic Symbols and the Self. Cambridge University Press. DOI: 10.1017/CBO9781139167611

Curasi, C. F., Price, L. L., Arnould, E. J. (2004). How Individuals' Cherished Possessions Become Families' Inalienable Wealth. Journal of Consumer Research. 31 (3). pp. 609-622. DOI: 10.1086/425096

Halbwachs, M. (1992). On Collective Memory. University of Chicago Press.

Hill, R. P. (1991). Homeless Women, Special Possessions, and the Meaning of 'Home': An Ethnographic Case Study. Journal of Consumer Research. 18 (3). pp. 298-310. DOI: 10.1086/209261

Hill, R. P., Stamey, M. (1990). The Homeless in America: An Examination of Possessions and Consumption Behaviors. Journal of Consumer Research. 17 (3). pp. 303-321. DOI: 10.1086/208559

Holt, D. B. (1997). Distinction in America? Recovering Bourdieu's Theory of Tastes from Its Critics. Poetics. 25 (2-3). pp. 93-120. DOI: 10.1016/S0304-422X(97)00010-7

Holý, L. (2001). Malý český člověk a skvělý český národ: národní identita a postkomunistická transformace společnosti. [Little Czech man and great Czech nation: national identity and the post-communist transformation of society]. Sociologické nakladatelství (in Czech).

Hug, Theo (2012). Media competence and visual literacy - towards considerations beyond literacies. Periodica Polytechnica Social and Management Sciences. 20 (2). pp. 115-125. DOI: 10.3311/pp.so.2012-2.06

Joy, A., Sherry, J. F. Jr. (2003). Speaking of Art as Embodied Imagination: A Multisensory Approach to Understanding Aesthetic Experience. Journal of Consumer Research. 30 (2). pp. 259-282. DOI: 10.1086/376802

Karlíček, M., Novinský, M., Tahal, R. (2014). Role marketingu ve firmách. Zlín: Radim Bačuvčík - VeRBuM (in Czech).

Kleine III, R. E., Schultz Kleine, S., Kernan, J. B. (1993). Mundane Consumption and the Self: A Social-Identity Perspective. Journal of Consumer Psychology. 23. pp. 209-235.

DOI: 10.1016/S1057-7408(08)80015-0

Kočí, J. (1978). Ceske narodni obrozeni [Czech National Awakening]. Praha: Svoboda (in Czech).

Kotler, P., Armstrong, G. (2001). Principles of marketing. Pearson Education. McCracken, G. (1986). Culture and Consumption: A Theoretical Account of the Structure and Movement of the Cultural Meaning of Consumer Goods. Journal of Consumer Research. 13 (1). pp. 71-84. DOI: 10.1086/209048

Moisander, J., Valtonen, A. (2006). Qualitative Marketing Research: A Cultural Approach. SAGE.

O’Sullivan, T. (1994). Key Concepts in Communication and Cultural Studies. Routledge. 
Peñaloza, L. (1994). Atravesando Fronteras/Border Crossings: A Critical Ethnographic Exploration of the Consumer Acculturation of Mexican Immigrants. Journal of Consumer Research. 21 (1). pp. 32-54. DOI: $10.1086 / 209381$

Petruska, I. (2002). Why should companies and universities co-operate in R and D? The marketing fundamentals. Periodica Polytechnica Social and Management Sciences. 10 (2). pp. 303-315.

Prelinger, E. (1959). Extension and Structure of the Self. The Journal of Psychology. 47 (1). pp. 13-23. DOI: 10.1080/00223980.1959.9916303

Price, L. L., Arnould, E. J., Folkman Curasi, C. (2000). Older Consumers' Disposition of Special Possessions. Journal of Consumer Research. 27 (2). pp. 179-201. DOI: 10.1086/314319

Sirgy, M. J. (1982). Self-Concept in Consumer Behavior: A Critical Review. Journal of Consumer Research. 9 (3). pp. 287-300. DOI: 10.1086/208924

Skitka, L. J. (2005). Patriotism or Nationalism? Understanding Post--September 11, 2001, Flag-Display Behavior. Journal of Applied Social Psychology. 35 (10). pp. 1995-2011. DOI: 10.1111/j.1559-1816.2005.tb02206.x
Spiggle, S. (1994). Analysis and Interpretation of Qualitative Data in Consumer Research. Journal of Consumer Research. 21 (3). pp. 491-503. DOI: $10.1086 / 209413$

St James, Y., Colbert, F. (2011). Staging Magic: Forty Years of Product Management at Théâtre Sans Fil. International Journal of Arts Management. 13 (3). pp. 69-78.

Thompson, C., Tian, K. (2008). Reconstructing the South: How Commercial Myths Compete for Identity Value through the Ideological Shaping of Popular Memories and Countermemories. Journal of Consumer Research. 34 (5). pp. 595-613. DOI: 10.1086/520076

Zaltman, G. (1997). Rethinking Market Research: Putting People Back In. Journal of Marketing Research. 34 (4). pp. 424-437.

DOI: $10.2307 / 3151962$

Zaltman, G., Coulter, R. H. (1995). Seeing the Voice of the Customer: Metaphor-Based Advertising Research. Journal of Advertising Research. 35 (4). pp. 35-51. 